\title{
Integrated Nitrogen Management in Rice Crop through Organic and Inorganic Sources
}

\author{
H. Shenoy" and M. N. Siddaraju \\ Department of Botany, University College, Mangalore University, \\ Mangalore, Karnataka, India \\ *Corresponding author
}

\section{A B S T R A C T}

\begin{tabular}{l} 
K e y w o r d s \\
$\begin{array}{l}\text { Nitrogen } \\
\text { management, } \\
\text { Rice crop }\end{array}$ \\
\hline Article Info \\
$\begin{array}{l}\text { Accepted: } \\
17 \text { August } 2020 \\
\text { Available Online: } \\
\text { 10 September } 2020\end{array}$ \\
\hline
\end{tabular}

Nitrogen is the nutrient which limits the most the rice production worldwide. Conjunctive use of organic material along with fertilizer has been proved to be an efficient source of nitrogen. Use of organic manures in conjunction or as an alternative to chemical fertilizer is receiving worldwide attention of the researchers in recent days.. The excessive application of chemical fertilizers made it imperative that a part of inorganic fertilizer may be substituted with the recycling of organic manures. Partial nitrogen substitution through organic manure recording beneficial effect on yield over farmer's practice has been reported by many research workers in rice. This implies for integrated use of organic and inorganic sources of nitrogen for maintaining yield stability. An attempt has been made to review the earlier works on integrated use of organics especially vermicompost, and poultry manure as sources of nitrogen applied with inorganic fertilizers on growth, yield and yield attributing traits in rice In conclusion, integrated application of $50 \%$ of nitrogen through inorganic sources with $50 \%$ from organic sources is the best combination reported by many workers having beneficial effect on rice yield and improvement of soil properties.

\section{Introduction}

Nitrogen $(\mathrm{N})$ is the most essential and limiting nutrient element required in large amounts for rice production and provision of adequate supply of $\mathrm{N}$ throughout the growing period is essential for realizing potential yields (Sureka et al 2016). Nitrogen promotes rapid plant growth and improves grain yield and quality through. higher tillering, leaf area development, grain formation, grain filling and protein synthesis (Pratap Reddy et al 2019) and plays a crucial role in enhancing the yield. Globally rice cultivation consumes approximately $9-10$ million $\mathrm{t}$ of fertilizer $\mathrm{N}$ in a year which accounts for about 10 per cent of the total $\mathrm{N}$ fertilizer production in the world (Nayak et al., 2018).

Nitrogen fertilizer is one of the main factors responsible for contributing to increase in rice yield (47\%) in India. However, low Nitrogen Use Efficiency (NUE) (30-40 per cent) caused by its overuse has led to environmental issues like soil acidity, degradation, water eutrophication, greenhouse 
gas emissions attracting global attention (Prasad et al., 2017). Achieving high NUE in rice production has become a major challenge with increasing food demand, depletion of natural resources and environmental deterioration. Hence development of efficient $\mathrm{N}$ management strategy for sustaining soil fertility and maximizing crop yields by partially substituting the chemical $\mathrm{N}$ fertilizers with suitable organic sources like farm yard manure, poultry manure, vermicompost, green manuring, neem cake and biofertilizers is gaining importance (Dahiphale et al., 2003) in the recent years. Substitution of chemical fertilizers with organic amendments will recycle organic wastes and minimizes adverse environmental effects of mineral-fertilizer overuse. Chemical fertilizers that are high grade in nitrogen supply and easily soluble in nature release nitrogen at a rapid rate when applied to rice. Organic manures with low concentrations of nutrients paired with other challenges such as slow releasing nature, high transport costs and limited availability may not be beneficial for rice when applied as the sole nitrogen source (Miah et al, 1994). The integration of organic manure with inorganic fertilizers is essential to achieve sustained production of rice and maintain the soil fertility for a longer period. (Gill and Walia, 2014).

Numerous studies have shown that long-term combined application of organic and inorganic fertilizer can improve crop yield in rice (Han et al., 2020; Qaswar et al., 2020); However, in these studies, organic amendments were added based on the chemical fertilizer dosage such that the total nutrient amounts in the field were increased. Little information is available regarding rice yield responses to organic substitution fertilizer regimes (in which one or more organic $\mathrm{N}$ substitution ratios are employed that maintain the total $\mathrm{N}, \mathrm{P}$, and $\mathrm{K}$ input equal to that of the mineral NPK regime).
Therefore, efforts to clarify the influences of organic substitution regimes under different organic-inorganic substitution ratios are needed to be developed for effective fertilizer strategies. Several studies indicated that application of fertilizer $\mathrm{N}$ in conjunction with organic sources is known to stimulate the mineralization and then immobilization of organic $\mathrm{N}$ and reduced the losses of nitrogen. Hence an attempt has been made to review the research conducted by several workers in rice to assess the performance of rice to nitrogen application when supplied through vermicompost and poultry manure under different organic and inorganic substitution ratios.

\section{Effect of vermicompost application on growth and yield parameters in rice}

Vermicompost is rich in plant nutrients like available nitrogen, phosphorus, potassium, calcium, vitamins, natural phyto-regulators and micro flora in balanced form that helps in re-establishment of the natural fertility of the soil (Arancon and Edwards, 2009). Several workers have reported beneficial effect of vermicompost when supplied as nitrogen source along with fertilizers in various proportions favorably influencing the growth and yield parameters of rice (Meena, 2003: Anitha and Prema, 2003)

In an experiment conducted at ZARS Mandya, Sidram et al., (2010) reported that application of Recommended Dose of Fertilizers (RDF) (100:50:50 kg NPK ha $\left.{ }^{-1}\right)$ with 10.0 tons $\mathrm{ha}^{-1}$ of Farm Yard Manure $(\mathrm{FYM}){ }^{1}$ recorded significantly higher plant height $(63.1 \mathrm{~cm})$, number of tillers $(36.2$ hill ${ }^{1}$ ) and leaf area $\left(1602 \mathrm{~cm}^{2}\right.$ hill $\left.^{-1}\right)$. However it was on par with application of vermicompost equivalent to 200 per cent recommended dose of nitrogen (RDN) where the plant height $(62.6 \mathrm{~cm})$, number of tillers $\left(35.1 \mathrm{hill}^{-1}\right)$ and leaf area $\left(1561 \mathrm{~cm}^{2}\right.$ hill $\left.^{-1}\right)$ was recorded. 
Studies by Ranjitha et al., (2013) indicated that application of 50 per cent RDN (inorganic) and remaining 50per cent RDN through vermicompost resulted in significantly higher growth parameters followed by treatment receiving $100 \% \mathrm{RDN}$ $\left(120 \mathrm{~kg} \mathrm{ha}^{-1}\right)$ through inorganic fertilizers. Dekhane et al., (2014) reported favorable growth and yield attributes with application of 50 per cent of nitrogen through vermicompost integrated with fertilizers resulting in higher the panicle length $(22.3 \mathrm{~cm})$, grains per panicle (128) 1000 grain weight (19.7 g) grain yield $\left(4.97 \mathrm{t} \mathrm{ha}^{-1}\right)$ and straw yield $(5.77$ $\mathrm{t} \mathrm{ha}^{-1}$ ) of rice variety GR-1.Aruna and Shaikh (2005) reported from Tirupati (Andhra Pradesh) that conjunctive use of 75 per cent $\mathrm{N}$ $\left(90 \mathrm{~kg} \mathrm{ha}^{-1}\right)$ through fertilizer and 25 per cent $\mathrm{N}\left(30 \mathrm{~kg} \mathrm{ha}^{-1}\right)$ through FYM or vermicompost significantly increased the rice yield compared to RDN of $120 \mathrm{~kg} \mathrm{~N}^{-1}$. Tripathi and Verma (2008) reported that the beneficial effect of vermicompost treated plots with higher number of filled grains (80.3 panicle $^{-1}$ ) and lower percentage of floret sterility (20.7) apart from nutrient supply and availability. Banik and Bejbaruah (2004) from Jharkhand reported that application of vermicompost at $15 \mathrm{~kg} \mathrm{~N}$ with with inorganic fertilizer of NPK dose (45-13-25 kg ha-1) gave rice yield equal to that of sole supply of NPKS (60-17.5-33-3 $\mathrm{kg} \mathrm{ha}{ }^{-1}$ ) through fertilizer. Vermicompost application at $10 \mathrm{t} \mathrm{ha}^{-1}$ along with RDF increased the uptake of nutrients such as nitrogen, phosphorus, potassium, calcium and magnesium by rice under vermicompost treatment than FYM (Roy and Singh, 2006). In an experiment conducted at Ankanapalle Ramalaxmi et al., (2012) concluded that production efficiency of rice increased with reduced chemical fertilizers levels and highest nitrogen use efficiency and yield was recorded with treatment receiving 75 per cent RDN integrated with vegetable market vermicompost at $2.5 \mathrm{tha}^{-1}$.
Application of vermicompost at $15 \mathrm{~kg} \mathrm{~N}$ in combination with NPK dose (45-13-25 $\mathrm{kg} \mathrm{ha}^{-1}$ ) as inorganic fertilizers gave rice yield equal to that of sole supply of NPKS (6017.5-33-3 $\mathrm{kg} \mathrm{ha}^{-1}$ ) through fertilizer (Banik and Bejbaruah, 2004). Barik et al., (2006) concluding a field experiment conducted at Sriniketan (West Bengal) reported that application of RDF (50 per cent) with vermicompost $10 \mathrm{tha}^{-1}$ significantly improved the growth and yield attributes of rice compared with the application of 100 per cent RDF (60:30:30) and of different combinations of FYM and mineral fertilizers. The highest grain and straw yield were recorded when crop was supplied with 50 per cent RDN along with $10 \mathrm{t} \mathrm{ha}^{-1}$ of vermicompost. Virktamath (2006) reported that maximum grain and straw yield was recorded with application of 50 percent RDN through urea with 50 percent RDN through vermicompost which was significantly superior over rest of the treatments followed by treatment which received 100 percent RDN through urea.

Paramesh et al (2014) reported that 50 per cent RDN through chemical fertilizers integrated with 50 per cent RDN through vermicompost recorded significantly higher plant height, leaf area, number of tillers hill ${ }^{-1}$ total dry matter accumulation hill ${ }^{-1}$ grain yield $\left(39.48 \mathrm{q} \mathrm{ha}^{-1}\right)$ and straw yield $\left(52.9 \mathrm{q} \mathrm{ha}^{-1}\right)$. In an experiment conducted at Varanashi, Kumar et al (2014) reported that application of 125 per cent RDF with $5.0 \mathrm{t} \mathrm{ha}^{-1}$ vermicompost increased the number of panicles (20.5 per cent), panicle length (23.12 per cent), panicle weight (13.02 per cent), 1000 grain weight (12.90 per cent), grain yield $(31.15 \%)$ and straw yield $(37.12$ per cent) over control where no fertilizer or vermicompost was applied. Vermicompost application at $5.0 \mathrm{t} \mathrm{ha}$ along $\mathrm{RDF}$ significantly improved the nutrient uptake of hybrid rice when compared to control (Balaji and Yakadari, 2004). Sultana et al (2015) 
found that highest amount of nitrogen (55.70 $\mathrm{kg} \mathrm{ha}^{-1}$ ) phosphorus $\left(13.79 \mathrm{~kg} \mathrm{ha}^{-1}\right)$ potassium $\left(92.43 \mathrm{~kg} \mathrm{ha}^{-1}\right)$ and sulfur $\left(6.91 \mathrm{~kg} \mathrm{ha}^{-1}\right)$ uptake by straw of rice were observed in treatment receiving $90 \mathrm{~kg} \mathrm{~N}^{-1}$ through urea integrated with $30 \mathrm{~kg} \mathrm{~N} \mathrm{ha}^{-1}$ from vermicompost. Kumar et al., (2014) conducted a field investigation at Varanasi (Uttar Pradesh) and revealed that application of 125 per cent $\mathrm{RDF}+5$ tons of vermicompost $\mathrm{ha}^{-1}$ recorded significantly highest $\mathrm{N}$ uptake in grain (36.81 per cent) and straw (42.81 per cent), $\mathrm{P}$ uptake in grain (32.62 per cent) and straw (31.56 per cent) and $\mathrm{K}$ uptake in grain (35.46 per cent) and straw (25.39 per cent) of rice over control followed by 100 per cent $\operatorname{RDF}(120-60-40 \mathrm{~kg}$ N-P-K/ha) $+5 t^{-1} a^{-1}$ vermicompost.

\section{Effect of poultry manure application on growth and yield parameters in rice}

The application of poultry manure to soil is considered as a good management practice in any agricultural production system because of the stimulation of soil microbial growth and activity, subsequent mineralization of plant nutrients, and increased soil fertility and quality (Arancon et al., 2006). Poultry manure contains major, secondary and micro nutrients that can support crop production and enhance the physical and chemical properties of soil. It improves soil retention and uptake of plant nutrients. (Mohammed et al., 2010)

Nasimul (2014) stated that mixing poultry litter with chemical fertilizers enhances the yield of crop and soil fertility and also minimizes the cost of fertilizer. Roy et al., (2015) reported that inorganic fertilizers along with manure greatly influence the yield contributing characters and yield of Boro rice. Application of poultry manure along with inorganic fertilizers increased grain yield, protein content and aroma in aromatic fine rice (Sarkar et al., 2014, Biswas et al 2016)
The combination of nitrogen from different organic manures was comparable to equivalent $\mathrm{N}$ basis in which poultry manure proved to be a better source and had beneficial effect on rice Budhar et al., (1991). This treatment also produced maximum number of tillers hill ${ }^{-1}$ which was on par with application of RDF (50-37.5-30 NPK kg ha-1) along with FYM applied at $20 \mathrm{t} \mathrm{ha}^{-1}$. The combined application of fertrilizer $\mathrm{N}$, vermicompost and azolla sustained the productivity even at lower rate of $\mathrm{N}$ fertilizer application (Singh et al, 2005). Laxminarayana and Patiram (2006) revealed that application of optimum dose of NPK (100-60-40 kg NPK ha' ${ }^{-1}$ in combination with green manure applied at $5 \mathrm{t} \mathrm{ha}^{-1}$ recorded highest grain and straw yield in rice followed by 100 per cent NPK (100-60-40 kg ha-1) + poultry manure $\left(5 \mathrm{t} \mathrm{ha}^{-1}\right)$. Maragatham et al (2010) reported that application of 50 per cent of $\mathrm{N}$ as Urea +50 percent of $\mathrm{N}$ as poultry manure recorded higher growth characters, yield attributes and grain yield in rice which was closely followed by application of 100 per cent $\mathrm{N}$ from fertilizer Urea. Higher profit was obtained with 50 per cent of $\mathrm{N}$ as Urea + 50 per cent of $\mathrm{N}$ as poultry manure.

Hossaen et al., (2011) evaluated the efficacy of different organic manure and inorganic fertilizer on the yield and yield attributes of Boro Rice.The maximum number of effective tillers (13.52 hill $\left.^{-1}\right)$, the longest panicle(24.59 $\mathrm{cm}$ ), maximum number of total grain plant-1 (97.45), the highest weight of 1000 seeds $(21.80 \mathrm{~g})$, the maximum grain yield $(7.30 \mathrm{t}$ ha-1) and straw yield (7.64 $\left.\mathrm{t} \mathrm{ha}^{-1}\right)$ was recorded from application of 70\% NPKS + 2.4 tonnes poultry manure $\mathrm{ha}^{-1}$ Sangeetha $e t$ al (2013) reported that application of poultry manure compost enriched with biofertilizers like Azotobacter, Azospirillum and Phosphobacteria on equal $\mathrm{N}$ basis $\left(2.3 \mathrm{t} \mathrm{ha}^{-1}\right)$ recorded higher grain and yield attributes of rice which was however comparable with 
composted poultry manure. Saidu and Abayomi (2015) reported from Nigeria that the rice grain yield was significantly higher in the treatment combination of 1.0 ton $\mathrm{ha}^{-1}$ of poultry manure $+20 \mathrm{~kg}$ Nitrogen $\mathrm{ha}^{-1}(2.51 \mathrm{t}$ $\left.\mathrm{ha}^{-1}\right)$ which recorded grain yield $\left(1.85 \mathrm{t} \mathrm{ha}^{-1}\right)$ compared to control $\left(1.38 \mathrm{t} \mathrm{ha}^{-1}\right)$. Amanullah et al (2016) reported that application of $90 \mathrm{~kg}$ $\mathrm{P} \mathrm{ha}^{-1}$ along with combined application of animal manures, especially poultry manure increases rice productivity. Syed et al (2019) in an experiment conducted at Killikulam (Tamil Nadu) observed higher grain yield of rice $\left(7160 \mathrm{~kg} \mathrm{ha}^{-1}\right)$ with application 75 percent of nitrogen through inorganic source with remaining 25 per cent of nitrogen being supplied by poultry manure.

Based on the results of the experiment conducted to study the effects of integrated organic and inorganic fertilizers on yield and growth of rice, Kyi moe et al., (2019) concluded that poultry manure which contains high total $\mathrm{N}$ (more than $4 \%$ ) and moderate $\mathrm{P}$ and $\mathrm{K}$ should be integrated with 50 per cent of the recommended chemical fertilizers to improve yield and reduce the amount of chemical fertilizers.

In conclusion the integrated nitrogen management through application of organic sources namely vermicompost, and poultry manure with inorganic fertilizer sources had beneficial effects when used in conjunction rather than sole source alone on improving rice yield, nutrient uptake and physicochemical properties of soil. From the array of research work reviewed, it can be concluded that that 50per cent from organic sources and 50 per cent from inorganic sources is the best combination reported by many workers for integrated soil fertility and sustaining yield in rice. Further the suitability of organic manures can be based on local availability or trial based for precise results as soil types and environment plays a major role and varies from place to place.

\section{References}

Arancon Q.N and Edwards C.A.. 2009. The utilization of vermicompost in Horticulture and Agriculture. In: Edwards CA, Jeyaraaj R, Indira AJ (Eds.) Vermitechnology in Human welfare. Rohini Achagam, Coimbatore, Tamil Nadu, India, pp 98-108.

Arancon N Q, Edwards C A, Bierman P. 2006. Influences of vermicomposts on field strawberries: Part 2. Effects on soil microbiological and chemical properties. Bio-resource Technology. 97: 831-840.

Aruna, E. and Shaikh.M. 2005. Influence of conjunctive use of organic and inorganic source of nutrients in rice on crop growth, yield components, yield and soil fertility in rice-sunflower (Helianthus annuus) sequence. Indian Journal of Agronomy, 50(4): 265-268.

Amanullah, Shams-ul-Tamraiz Khan, Asif Iqbal, and Shah Fahad., 2016. Growth and Productivity Response of Hybrid Rice to Application of Animal Manures, Plant Residues and Phosphorus. Frontiers of Plant Science. 7:1440.

Anitha. S and A. Prema.2003. Vermicompost boosts crop production. Indian Farming 52 (20):15-18.

Budhar. M N., S. P. Palaniappan and A Rangaswamy 1991. Effect of farm wastes and green manures on low land rice. Indian J of Agronomy 36: 251-252.

Balaji N. B and Yakadri M, 2004. Effect of integrated nutrient management in hybrid Rice (Oryza sativa. L) . Journal of Research ANGARU 36(1):10-13

Banik P and Bejbaruah R, (2004) Effect of Vermicompost on Rice yield and soil fertility status of rainfed humid subtropics. Indian Journal of Agricultural Sciences. 74(9)488-491.

Barik A K, Arindam Das, A K Giri and G N Chattopadhyay, 2006. Effect of organic 
(Vermicompost, Farmyard Manure) and chemical sources of palnt nutrients on productivity and soil fertility of Kharif rice (Oryza sativa L.) Crop Research 31(3): 339-342

Biswas T, Paul S K, Sarkar M A R, Sarkar S K. 2016. Integrated use of poultry manure with prilled urea and urea super granules for improving yield and protein content of aromatic rice (cv. BRRI dhan 50). Progressive Agriculture, 27: 86-93

Dekhane, S. S., Patel, D. J., Jadhav, P. B., Kireeti, A., Patil, N. B., Harad, N. B. and Jadhav,

K. P. 2014. Effect of organic and inorganic fertilizer on growth and yield of paddy cultivar GR-11. International Journal of Information Research and Review, 1(2): 026-028.

Dahiphale A. V. D. G. Giri, G. V. Thakre and M. D. Gin, 2003. Effect of Integrated Nutrient Management on Yield and Yield Contributing Parameters of the Scented Rice, Annals of Plant Physiology, 17 (1) 24-26.

Gill J.S. and Walia S. S. 2014. Influence of FYM, brown manuring and nitrogen levels on direct seeded and transplanted rice (Oryza sativa L.) A Review. Research Journal of Agriculture and Environmental Management. 3(9): 417426.

Hossaen M.A, A.T.M. Shamsuddoha, A.K.Paul,M. S. I. Bhuiyan and A. S. M. Zobaer, 2011 efficacy of different organic manures and inorganic fertilizer on the yield and yield attributes of boro rice The Agriculturist 9 (1\&2): 117-125.

Han. X, C. Hu, Y. Chen, Y. Qiao, D. Liu, J. Fan, S. Li, Z. Zhang (2020) Crop yield stability and sustainability in a ricewheat cropping system based on 34year field experiment European Journal of Agronomy 113: 125965.

Kumar, A. N. Meena, Lalji Yadav and Y. K. Gilotia, 2014. Effect of Organic and
Inorganic Sources of Nutrient on Yield, Yield Attributes and Nutrient Uptake of Rice cv. PRH-10, The Bioscan 9(2) 595-597

Kyi Moe1, Seinn Moh Moh, Aung Zaw Htwe1, Yoshinori Kajihara, Takeo Yamakawa, 2019. Effects of integrated organic and inorganic fertilizers on yield and growth parameters of rice varieties Science Direct Rice Science, 26(5): $309-318$

Laxminarayana. K and Patiram. R, 2006. Effect of integrated use of inorganic biological and organic manures on rice productivity and soil fertility in ultisols of Mizoram. Journal of Indian Society of soil science 54 (2) 213-220.

.Miah M M U. 1994. Prospects and problems of organic farming in Bangladesh. Paper presented at the Workshop on Integrated Nutrient Management for Sustainable Agriculture held at SRDI, Dhaka: 26-28.

Maragatham. N. 2010. Direct effect of organic and bio-digested organic manures on groundnut and their residual effect on lowland rice in groundnut rice cropping system. Ph.D. Thesis, Tamil Nadu Agricultural University, Coimbatore, India

Mohammed $M$ A.,S Sekar. And P Muthukrishnan 2010. Prospects and Potential of Poultry Manure,Asian Journal of Plant Sciences 9(4):172-182.

Meena K C. 2003. Vermiculture in relation organic farming. Indian Farming 52(12): 27-30

A K Nayak, S Mohanty D Chatterjee, D Bhaduri, R Khanam, M Shahid, R Tripathi, A Kumar, S Munda, U Kumar, $\mathrm{P}$ Bhattacharyya, BB Panda and $\mathrm{H}$ Pathak. 2018. Nutrient Management for Enhancing Productivity and Nutrient Use Efficiency in Rice in: Rice Reseacrch for enhancing productivity and profitability and climate resilience. 
Published by ICAR- National Rice Research Institute, Cuttack-753006, Odisha, India

Nasimul G. 2014. Impact of poultry litter on soil properties and production of jute. Ph. D thesis, University of Dhaka, Bangladesh.

Prasad. R, Y.S. Shivay and D. Kumar. 2017. Current status, challenges, and opportunities in rice production In: Rice Production Worldwide (Eds. Chauhan, K. Jabran, G. Mahajan), Springer International Publishing. pp. 1-32.

Prathap Reddy, N. C H. Bharat Bhushan Rao, K.Surekha and Hussain, S. 2019. Transplanted rice as influenced by different enriched nitrogen sources-An economic appraisal. International Journal of Current Microbiology and AppliedSciences 8(06):3229-3231. doi: https://doi.org/10.20546/ijcmas.2019.80 6.384

Paramesh V., C J Sridhara., K S Shashidhar and S. Bhuvaneshwari,2014. Effect of integrated nutrient management and planting geometry on growth and yield of aerobic rice. International Journal of Agricultural Sciences, 10: 49-52

M. Qaswar, H. Jing, W. Ahmed, L. Dongchu, L. Shujun, Z. Lu, A. Cai, L. Lisheng, X. Yongmei, G. Jusheng, Z. Huimin Yield sustainability, soil organic carbon sequestration and nutrients balance under long-term combined application of manure and inorganic fertilizers in acidic paddy soil, Soil Tillage Research., 198 (2020), Article 104569

Roy D K and Singh B P. 2006. Effect of level and time of nitrogen application with and without vermicompost on yield and yield attribute and quality of Malt Barley (Hordeum vulgare.) Indian Journal of Agronomy, 51(1)40-42.

Roy B, Sarkar M A R, Paul SK 2015. Effect of integrated nutrient management in rice cultivation. SAARC Journal of
Agriculture, 13 (2): 131-140.

Rama Lakshmi, P.C. Rao, T. Sreelatha, M. Madahvi, G. Padmaja, P.V. Rao and Sireesha, 2012. Nitrogen Use Efficiency and Production Efficiency of Rice Under Rice-Pulse Cropping System with Integrated Nutrient Management. Journal of Rice Research, 5(1 \& 2) 4251.

Ranjitha P, Sri Raju, M. Srinivasa., Kumar R., Mahender., Jayashree.G. 2013. Effect of cultivars and nutrient management 6practices on growth, yield attributes Integrated Nutrient Management. Journal of Rice Research (1 \& 2) 52-56.

Sarkar S. K, Sarkar M A R, Islam N, Paul S K (2014). Y ield and quality of aromatic fine rice as affected by variety and nutrient management. Journal of Bangladesh Agricultural University, 12(2): 279-284.

Singh R K K., H S Athokpam, Z Changte and $\mathrm{N} \quad \mathrm{G}$ Singh.2005. Integrated manewgement of Azolla, vermicompost and urea on yield and nutrient uptake by rice and soil fertility. Journal of Indian Society of Soil Science, 53(1): 107-110.

Siddaram, K. Murali, B.N. Manjunatha, Y.M. Ramesha, M.K. Basavaraja and A.S. Policepatil 2010. Effect of nitrogen levels through organic sources on growth, dry matter production and nutrient uptake of irrigated aerobic rice (Oryza sativa L.) International Journal of Agricultural Sciences, 6 (2): 426-429

Sangeetha S. P, A. Balakrishnan, P. Devasenapathy 2013 Influence of organic manures on yield and quality of Rice (Oryza sativa L.) and Blackgram (Vigna mungo L.) in Rice-Blackgram Cropping Sequence American Journal of Plant Sciences, 4: 1151-1157.

Saidu A and Y. A. Abayomi. 2015. Interactive effects of organic and inorganic fertilizers on the performance of Upland Rice (Oryza sativa 1.) 
Cultivars, International Journal of Agricultural sciences 5 (2) 399-406.

Surekha K R, Mahendra Kumar V, Nagendra

N, Sailaja T, Satyanarayana, 2016, 4R nitrogen management for sustained rice production better crops South Asia, pp. 18-19.

Sultana M S., M H Rahman, M S Rahman, S Sultana and A K Paul.2015. Effect of integrated use of vermicompost, pressmud, and urea on nutrient content of grain and straw of Rice, International Journal of Scientific and Research Publications, 5(11): 765-770.

Syed A. H H, Sathiya and Nallaih Durairaj 2019. Integration of different organic manures and nitrogenous fertilizer and its effect on growth and yield of rice. Journal of Pharmacognosy and Phytochemistry, 8(2):415-418.

Tripathi N. and Verma R S 2008. Performance of Basmathi Rice under organic sources of Nutrition. International Journal of Agricultural Sciences, 4(1): 301-305.

Viraktamath B C. 2006. Evaluation of System of Rice intensification (SRI) under All India Coordinated Rice Project. In: Nationl Symposium on System of Rice Intensification (SRI), Present Status and Future prospects, $17-18^{\text {th }}$ November, Pp. 205-213.

\section{How to cite this article:}

Shenoy, H. and Siddaraju, M. N. 2020. Integrated Nitrogen Management in Rice Crop through Organic and Inorganic Sources. Int.J.Curr.Microbiol.App.Sci. 9(09): 2297-2304. doi: https://doi.org/10.20546/ijcmas.2020.909.286 